



\section{discurso}

Revista do Departamento de Filosofia da USP n. 44 - 2014 


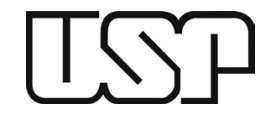

Universidade de São Paulo

Reitor: Marco Antonio Zago

Vice-Reitor: Vahan Agopyan

Faculdade de Filosofia, Letras e Ciências Humanas Diretor: Sérgio França Adorno de Abreu Vice-Diretor: João Roberto Gomes de Faria

Departamento de Filosofia Chefe: Roberto Bolzani Filho Vice-Chefe: Luiz Sérgio Repa

Editor Responsável

Pedro Paulo Pimenta

Editor convidado (artigos)

Fernão de Oliveira Salles

Editores Executivos

Milton Meira do Nascimento, Pedro Fernandes Galé, Marie Marcia Pedroso

Comissão Executiva

Homero Silveira Santiago, Lorenzo Mammì, Marco Sacrini Aguiar Ferraz, Márcio Suzuki, Maurício Cardoso Keinert, Oliver Tölle 


\section{discurso}

Revista do Departamento de Filosofia da USP

\section{Conselho Editorial}

Baltazar Barbosa $\uparrow$, Benedito Nunes $\uparrow$, Bento Prado Júnior $\uparrow$, Danilo Marcondes (PUC-RJ), Francis Wolff (École Normale Supérieure - Paris), Gerd Bornheim †, Gilles-Gaston Granger (Collège de France), Guido de Almeida (UFRJ), Henrique C. de Lima Vaz †, João Paulo Gomes Monteiro (USP), José Arthur Giannotti (Cebrap/USP), Marcos Müller (Unicamp), Maria Sylvia de Carvalho (USP/ Unicamp), Marilena de Souza Chaui (USP), Michel Paty (Universidade de Paris VII), Newton Carneiro Affonso da Costa (USP), Oswaldo Chateaubriand (UFRJ), Oswaldo Porchat de Assis Pereira da Silva (USP), Otília Beatriz Fiori Arantes (USP), Paulo Eduardo Arantes (USP), Raul Landim Filho (UFRJ), Rubens Rodrigues Torres Filho (USP), Ruy Fausto (Universidade de Paris VIII/USP), Victor Knoll (USP)

n. $44-2014$

ISSN $0103-328 \mathrm{X}$

Publicação anual

Endereço para correspondência:

Departamento de Filosofia - FFLCH - USP

Av. Prof. Luciano Gualberto, 315

CEP $05508-900$

Tel./Fax: (11) 3091-3761

Endereço eletrônico: http://filosofia.fflch.usp.br/publicacoes/discurso

E-mail: publicdf@usp.br

Bibliotecária Assessora: Maria Aparecida Laet

Secretária: Marie Márcia Pedroso

Tiragem: 1.000 exemplares
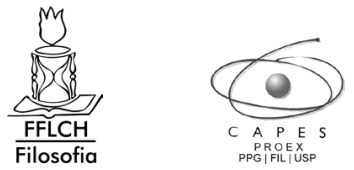


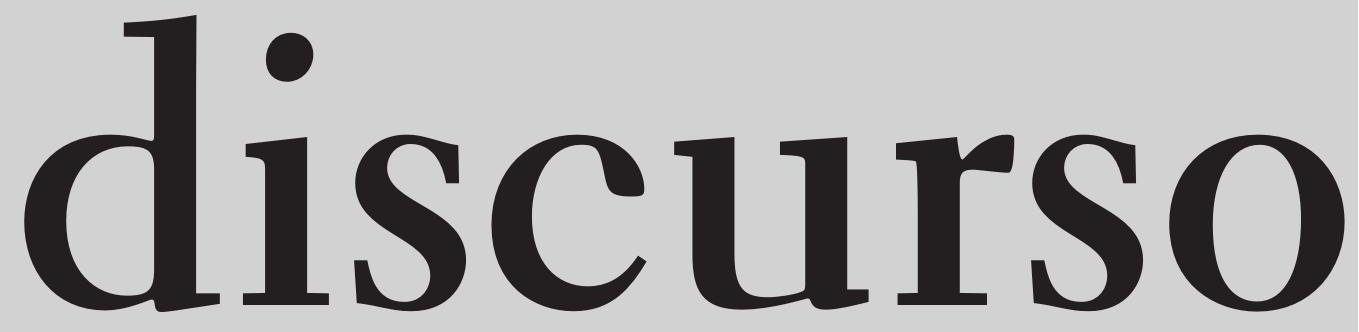




\section{São Paulo, 2014}

\section{ÍNDICE}

Raízes filosóficas da noção de ordem nos fisiocratas

Luiz Roberto Monzani

Q

Cidadania e liberdade: Rousseau contra Hobbes

Yara Frateschi

\section{5}

Hutcheson sobre a importância de ser desinteressado. Um encômio a Shaftesbury?

Laurent Jaffro

79

Francis Hutcheson, da beleza à perspectiva do desígnio

Lisa Broussois

97

Um comentário sobre as "regras para se julgar sobre causas e

efeitos" de David Hume

Mark Julian Richter Cass †

\section{7}

Literatura e formação moral em Jane Austen e em David Hume

Marcos Ribeiro Balieiro

145 
Voltaire sobre Shakespeare e Newton ou o gênio e o gosto nas artes e ciências Rodrigo Brandão

161

O Século das Luzes e o medo do escuro - a fantasia na Antropologia de Kant Luís Fernandes dos Santos Nascimento

189

A graça da virtude

Leonardo Rennó R. Santos

219

A concepção de ética no utilitarismo de John Stuart Mill Maria Cristina Longo Cardoso Dias

\section{5}

Resenhas

261

Traduções

277

Resumos $\mid$ Abstracts

295 


\title{
Raízes filosóficas da noção de ordem nos fisiocratas*
}

\author{
Luiz Roberto Monzani
}

UNICAMP/UFSCAR

* Publicado originalmente em tiragem de edição limitada pela editora Pedro \& João (São Carlos, 2007).

\section{discurso 44}


Para Bento Prado Jr., in memoriam 
1. Nosso propósito nesta discussão é relativamente simples. Gostaríamos, portanto, de deixar claros os limites dentro dos quais vamos tentar nos mover. Tentaremos, em primeiro lugar, questionar o óbvio: se há uma filiação com relação à noção de ordem de Malebranche nos fisiocratas. Isso já foi notado e apontado inúmeras vezes desde o século XIX. Só para citar alguns exemplos mais recentes, na década de $30 \mathrm{P}$. M. Schull escreveu um artigo na Revue Philosophique de la France et de l'Étranger onde essa relação é comentada (Schull, 1938, p. 313-5). Em 1958, Kubota escreveu um artigo numa coletânea (Kubota, 1958, p. 169-96), cujo título já é revelador "Quesnay disciple de Malebranche". Mais recentemente, G. Rodis-Lewis, num livro dedicado à Malebranche (1963, p. 329), comenta também essa proximidade. Um outro autor a apontar essa relação é o Prof. Rolf Kuntz, no seu belo livro Capitalismo e Natureza (1982, p. 114). Essa afinidade é geralmente aceita e muito pouco discutida.

2. Nossa intenção é outra. Queremos salientar a significação e as implicações dessa filiação. Significação, em primeiro lugar que, na maioria das vezes, essa filiação é quase sempre indicada, sobretudo baseando-se na aproximação superficial de alguns textos de Malebranche e outros dos fisiocratas, que nem sempre deixam claro ao leitor que essa filiação é mais que uma filiação superficial; e, também, pela razão - que o exame mais atento dos textos mostra - que há sérias dificuldades em se estabelecer essa filiação.

3. Em segundo lugar, e aqui seremos mais breves, gostaríamos também de examinar de uma maneira sumária, mas persuasiva, as implicações dessa filiação tanto nos próprios fisiocratas, quanto em alguns pensadores posteriores, i.e., nós gostaríamos de pelo menos apontar a importância da noção de ordem (e seu par oposto: desordem) na constituição de certos setores do que hoje nós denominamos ciências humanas. Aqui pretendemos já colocá-los 
de sobreaviso sobre outra limitação de nossa discussão. Quando falamos em implicações, não estamos pensando nem em implicações para ou na teoria econômica, nem mesmo na história das ideias ou doutrinas econômicas, domínios de onde, pelo pouco que já lemos, seria perfeitamente possível extrair algumas implicações. Como somos relativamente leigos nesses assuntos, vamos procurar retirar algumas implicações nos domínios da filosofia política e da sociologia. Isso posto, passemos ao assunto propriamente dito.

4. Os historiadores do pensamento econômico estão, em geral, de acordo - e nesse ponto confluem as opiniões de pensadores tão díspares como Marx e Schumpeter - em apontar nos fisiocratas os verdadeiros fundadores da economia política, ou melhor, de serem os responsáveis pela delimitação do econômico como um domínio particular, sujeito a leis internas e a um conjunto de relações intraespecíficas que lhe são peculiares. É bem verdade que os problemas econômicos preocupavam desde há muito tempo os sábios. Os canonistas elaboraram inúmeras reflexões sobre o campo econômico e, sobretudo, as descobertas marítimas, desencadearam um conjunto de reflexões que pouco a pouco foram na direção de um tratamento cada vez mais acurado das questões econômicas. Já em 1615 Montchrétien publica um Traité de economie politique e as publicações se multiplicam, passando por $\mathrm{W}$. Petty, Vauban, Boisguilebert (1965) e Cantillon (1959)1¹. Mas, é seguramente a publicação do Tableau Économique, de Quesnay, que constitui, segundo os historiadores, o ponto de inflexão do pensamento econômico. Marx diz o seguinte, a respeito do movimento fisiocrata (opinião compartilhada pela maioria dos historiadores do pensamento econômico):

1 Quem quiser ter uma ideia das principais publicações no campo econômico, no período anterior aos fisiocratas, poderá consultar o pequeno livro de Deyon (lg83, p. 7-11). 
Corresponde aos fisiocratas a honra de ter analisado o capital na sociedade moderna. Isto lhes dá o direito de se considerarem como os verdadeiros fundadores da moderna economia. Foram os primeiros que analisaram os diversos elementos materiais em que o capital existe e se manifesta durante o processo de trabalho. Não se lhes pode fazer a censura como a seus antecessores, de enfocar todas essas condições materiais, os instrumentos de trabalho as matérias primas etc. separadas das condições sociais que os rodeiam dentro da produção capitalista; dizendo as coisas de outra maneira de considerá-las através da forma que revestem como elementos do processo de trabalho, em geral fazendo caso omisso de sua forma social de capital e erigindo assim a forma capitalista de produção numa forma natural preestabelecida e perene. Está claro que eles não podiam deixar de ver, nas formas burguesas de produção formas naturais, mas tiveram o grande acerto de conceber essas mesmas formas como formas fisiológicas da sociedade, impostas pela necessidade natural da produção ou independentes da política, da vontade etc. Trata-se de leis materiais (Marx, 1974, p. 26).

5. Quer dizer, coube a Quesnay e aos fisiocratas o mérito de serem os primeiros a fornecer uma ideia clara e distinta de um novo "continente teórico" que é o domínio do econômico como um todo coerente, como um conjunto construído por partes interligadas entre si. Isto é, com os fisiocratas, pela primeira vez na história das ideias, passa-se de um conjunto de observações mais ou menos esparsas, isoladas; do estabelecimento de correlações sem contexto, para a ideia de um todo organizado, ordenado, de um sistema global de interrelações que abarcam a totalidade do domínio. Schumpeter diz que foram os fisiocratas, e, sobretudo, Quesnay, quem pela primeira vez formulou explicitamente o problema da interdependência, e que deu ao problema fundamental da economia política - equilíbrio (estático) entre quantidades interdependentes - uma “imagem”: o Tableau Économique 
(Schumpeter, 1967 , p. 242-3)2². Deve-se, portanto, reconhecer aos fisiocratas o mérito de terem sido os primeiros a apresentar uma análise de conjunto da atividade econômica e de ter visualizado a Economia como um sistema coerentemente lógico de relações causais. Mas, enfim, qual ou quais eram as doutrinas professadas por Quesnay e por seus discípulos?

6. Já nos fins do século XVIII começa-se esboçar um conjunto de ideias que vão influenciar a formação do pensamento fisiocrático. A França, desde os fins do século, encontrava-se num lastimável estado financeiro. O fracasso da política mercantilista e, sobretudo, de Colbert, era patente e, já no fim desse mesmo século, Boisguilbert, em 1695, escreve um texto - "Le Détail de la France" -, no qual assinalava uma série de erros administrativos e apresentava alguns planos de reforma, assinalando como a agricultura, segundo ele a atividade mais importante do país, se arruinava pelos entraves do comércio de grãos impostos pela política mercantilista. Boisguilbert é considerado por muitos autores como o precursor do pensamento e das doutrinas fisiocráticas. Seu pensamento foi profundamente influenciado pelo pensamento jansenista e, mais particularmente, por P. Nicole, de onde extraiu suas principais teses, como mostra o interessante artigo de Facarello (1984, p. 35-6). Quesnay conhecia, admirava e citava Boisguilbert, sobretudo sua tese de substituir essa multidão de im-

2 Marx, 1974, p. 56: "A tentativa de Quesnay pode resumir-se do seguinte modo: representar todo processo de produção do capital como um processo de produção, a circulação como uma simples forma desse processo e a circulação do dinheiro como um elemento da circulação do capital; englobar nesse processo de reprodução as origens da renda, e troca entre a renda e o capital, a relação entre o consumo reprodutivo e o consumo definitivo; englobar na circulação do capital a circulação entre os consumidores e os produtores (entre o capital e a renda, na realidade): finalmente representar a circulação entre os dois grandes ramos da divisão do trabalho produtivo (produção bruta e produção industriai) como elementos desse processo de reprodução, e comprimir tudo isso - no primeiro terço do século XVIII, na fase inicial da economia política - num Quadro de cinco linhas, com seis pontos de partida ou de término. Jamais a economia política concebeu uma ideia tão genial". 
postos, que atravancava a atividade econômica francesa, por um imposto único. Quesnay retorna essa tese e a incorpora a outras, que também não são especificamente suas, através das quais ele elabora um quadro original e próprio.

7. Em primeiro lugar, para Quesnay, a única atividade produtiva, ou melhor, a única atividade que cria riquezas é a agricultura e, portanto, a terra é a fonte de toda riqueza. Quesnay diz textualmente:

A terra é a única fonte de riqueza [...] e é a agricultura que a multiplica. Porque o aumento de riquezas assegura o da população; os homens e as riquezas fazem prosperar a agricultura, estendem o comércio, animam a indústria, acrescentam e perpetuam as riquezas. Desta fonte abundante depende o êxito de todas as partes da administração do reino (Quesnay, 1967, p. 47).

Num outro texto, Quesnay diz a mesma coisa:

Assim, a origem, o princípio de todo gasto e de toda riqueza é a fertilidade da terra, cujos produtos não podem multiplicar-se senão por seus produtos mesmos (Quesnay, 1967, p. 80).

8. Segundo essa ótica é que Quesnay analisa, vê e compreende a sociedade. A função básica, a obrigação fundamental de toda administração e de todo governo, deve ser favorecer e facilitar ao máximo o desenvolvimento da agricultura, já que é ela a fonte de toda riqueza e, portanto, da riqueza e da opulência de qualquer nação:

[...] tudo o que é desvantajoso para a agricultura é prejudicial à Nação e ao Estado, e tudo que favorece a agricultura é proveitoso para o Estado e para a Nação (Idem, 1978, p. 254). 
Nesse sentido, tudo que for favorável ao livre desenvolvimento da agricultura deve ser incentivado ao máximo: quebra de entraves burocráticos, simplificação dos impostos, liberdade de cultivo, livre comércio interior e exterior, e assim por diante.

9. Essa tese, da terra como única riqueza, tem sua contrapartida numa outra defendida por Quesnay - que mais gerou oposição - a qual diz que o comércio, a manufatura e a indústria não são produtores de riquezas, mas realizam um puro jogo de equivalências. Se aos que trabalham a terra, Quesnay denomina a classe produtiva, a esta última ele denomina estéril - termo não muito feliz, convenhamos - o que não significa dizer que ela é inútil aos seus olhos. Ela apenas não produz riquezas. Daí o porquê se deve dar sempre preferência à agricultura, frente à manufatura (Id., 1967, p. 49) $3^{3}$. Mas o que Quesnay quer dizer com isso, com essa desvalorização da manufatura e da indústria? Tomemos alguns textos.

10. No segundo diálogo, ao seu opositor, que lhe havia retrucado o seguinte:

Isso poderia ocorrer se eu limitasse a produção unicamente às riquezas que nascem da terra; mas não posso ocultar-lhe que vejo sempre uma verdadeira produção nos trabalhos dos artesãos, pese a todas as dissertações publicadas desde algum tempo para fazer com que tal produção desapareça.

Quesnay diz:

3 "Que uma nação que possui um grande território para cultivar e a facilidade de exercer um grande comércio dos gêneros do país não estenda demasiado o emprego do dinheiro e dos homens às manufaturas e ao comércio de luxo, em prejuízo dos trabalhos e dos gastos da agricultura, porque, com preferência a tudo, o reino deve estar bem povoado de ricos cultivadores" (grifo nosso). 
Não se pretende que desapareça a produção dos trabalhos formados pelas tarefas dos artesãos porque, sem dúvida, é a produção mesma que você vê nesses trabalhos. Mas você deve notar [...] que não se trata de tal produção, isto é, de uma simples produção de formas que os artesãos dão à matéria de seus trabalhos, senão de uma produção real de riqueza, digo real, porque não quero negar que exista adição de riquezas à matéria prima das obras formadas pelos artesãos, posto que o trabalho aumenta, com efeito, o valor da matéria prima de suas obras (Ibid., 1967, p. 75-6).

Devemos confessar que a posição de Quesnay não é muito clara a respeito desse assunto, e não é de se espantar que ela tenha gerado tantas confusões. Simplificando um pouco as coisas, pode-se dizer que, para Quesnay, na manufatura não há produção real de riqueza, porque o que se tem é adição de riqueza ou trabalho e, em nenhum dos dois casos, houve um aumento real de riqueza, mas apenas uma adição que produz, no circuito econômico, um sistema de equivalências. Quesnay usa um exemplo esclarecedor de seu pensamento. Quando um operário vende uma sua obra, o que acontece? Quando, p. ex., o sapateiro vende um par de sapatos. Ele vende a matéria prima e o seu trabalho, cujo valor é determinado pelos dispêndios em produtos ou mercadorias que são necessários à sua subsistência e à de sua família. Só há nesse processo, portanto, consumo, diz Quesnay, e não produção. Mas não há, pelo menos, a produção de um par de sapatos, poder-se-ia objetar? Não, responde Quesnay, se se distingue entre a matéria prima e a obra, a única diferença que se encontra será a da forma que lhe foi dada pelo sapateiro (Id., 1978, p. P. 227). Agora temos a impressão que o pensamento de Quesnay fica claro: não se deve confundir produção com informação que acrescenta valor, mas não o cria:

Deve-se distinguir uma adição de riquezas reunidas de uma produção de riquezas, quer dizer, um aumento por reunião de matérias primas e de gastos em consumo de coisas que existiam antes dessa classe de aumento 
de uma geração ou criação de riquezas, que forma uma renovação e um acréscimo real de riquezas renascentes (Id., 1967, p. 77).

O mesmo obviamente vale, com muito mais razão, para o comércio:

O comércio é uma troca entre coisas que existem e que têm, cada uma delas, o seu valor respectivo. Existe ainda a necessidade de trocar, condição sem a qual não haveria qualquer troca ou comércio; todas essas coisas precedem a ação de trocar; a troca ou o comércio não faz nascer os produtos: a ação de trocar não produz, portanto, nada; é somente necessária para satisfazer uma necessidade que é, ela própria, a causa da troca. Temos, pois, que distinguir aqui entre o que é simplesmente necessário e o que é produtivo: se aquilo que é produtivo é necessário, daí não se segue, como insinua o autor, que tudo que é necessário seja produtivo (Id., 1978, p. 234).

Não se trata de examinar aqui o acerto ou o desacerto dessa doutrina de Quesnay. Nosso propósito não é - e nunca será - o de fazer esse tipo tão frequente de história das ideias, que julga o autor em questão segundo os critérios dos conhecimentos e das doutrinas aceitas atualmente. Pese o seu imenso valor, e a sua enorme erudição, esse é, a nosso ver, o maior defeito da História de Schumpeter. Para nossos propósitos, basta compreender as ideias e as doutrinas de um autor, no caso em questão, Quesnay.

11. Isso tudo nos leva a um outro ponto. Com esses elementos em mãos, Quesnay elabora a visão que tem da sociedade, do ponto de vista econômico. O autor tem uma visão da sociedade que é bem próxima daquela dos moldes tradicionais. A sociedade francesa que ele concebe é a sociedade do "Ancien Régime”. Esse é um dos muitos paradoxos de Quesnay: o homem que funda a economia moderna tem uma visão profundamente tradicionalista 
da sociedade e de seu mecanismo econômico. L. Dumont, num livro que não deixa de ter aspectos interessantes - Homo Aequalis - assinalou o paradoxo de que, além de Quesnay representar um grande passo no pensamento econômico, vivendo num país economicamente atrasado, ele cria um paradoxo interno, na sua própria doutrina. Suas palavras:

O Doutor Quesnay nos apresenta um paradoxo, do consenso comum, o pensamento econômico deu um grande passo adiante, graças ao gênio desse homem. E, entretanto, ele não vivia no país economicamente mais progressivo de seu tempo, a Inglaterra $[\ldots]$ - mas o paradoxo se reencontra em toda sua doutrina: a indústria e o comércio são pouco estimados e a agricultura é exaltada.

De certa maneira, pode-se dizer, segundo L. Dumont, que o paradoxo de Quesnay está no fato de que:

Quesnay descreve a velha sociedade de um novo ponto de vista: sua visão social e política é inteiramente tradicional, sob muitos aspectos, e no interior dessa visão ele instala um sistema propriamente econômico que é quase inteiramente moderno (Dumont, 1991, p. 50 e 52).

12. Bem, mas qual é, enfim, essa visão de Quesnay? Segundo ele, a sociedade é composta por três classes de cidadãos: a classe produtiva, a classe dos proprietários e a classe estéril.

a) A classe produtiva é a que se dedica ao trabalho e ao cultivo da terra. É ela que faz renascer anualmente a riqueza das nações, através desse mesmo cultivo. Ela faz os adiantamentos para os gastos nos trabalhos agrícolas e, também, paga anualmente os rendimentos dos proprietários;

b) A classe dos proprietários "compreende o soberano, os possuidores das terras e os dizimeiros". Essa classe subsiste através do rendimento ou produto líquido do cultivo que lhe é pago anualmente pela classe produtiva, depois que a classe produtiva 
deduziu as despesas e os adiamentos, assim como suas riquezas de exploração;

c) A classe estéril é, então, aquela formada pelos cidadãos que se ocupam de todas as atividades e de todos os trabalhos que não os da agricultura. Suas despesas são pagas pela classe produtiva e proprietária, sendo que a classe proprietária, como fica claro, obtém também seus rendimentos da classe produtiva (Quesnay, 1978, p. 239-40).

13. É a partir dessa visão das classes sociais e de suas atividades de Quesnay monta seu famoso "Tableau Économique", que consiste numa espécie de resumo visual, numa imagem do circuito econômico da sociedade. A intenção de Quesnay foi a de construir algo que a um simples olhar fornecesse uma visão imediata do funcionamento econômico da sociedade. É o que ele diz numa carta a Mirabeau:

Tentei construir um Quadro fundamental da ordem econômica, para nele representar as despesas e os produtos de um modo fácil de compreender, e para julgar claramente as coordenações que o governo pode realizar e as descoordenações que pode introduzir. Vereis se consegui o meu propósito (Ibid., 1978, p. 63).

14. Na verdade, Quesnay não foi muito feliz na composição desse Quadro. Pelo menos até hoje ele provoca polêmicas, e não conseguiu unanimidade sobre o seu significado. Alguns o consideram uma obra genial (Marx, Schumpeter); outros, como algo destituído de sentido. A confusão, na verdade, já começa com o lançamento do Quadro. O próprio Mirabeau - que mais tarde seria o apóstolo mais dedicado do fisiocratismo - já se viu imerso em profunda confusão. Numa segunda carta que Quesnay escreve a Mirabeau, ele diz, logo de início:

Diz-me a Sra. Marquesa de Pailli que ainda estás perplexo diante do 
ziguezague. É verdade que ele se liga com tantas coisas que é difícil apreender suas relações ou, mais que isso, penetrar sua evidência $[\ldots]$ (Ibid., 1978, p. 73).

Entre seus próprios contemporâneos, essa perplexidade ia às raias do desprezo. Na opinião de alguns, do economista Linguet, p.ex., nem sequer havia o que entender. Esse autor escrevia o seguinte:

Mas, digam-me de boa fé, conhecem alguém que o tenha entendido (o Quadro)? O próprio autor saberá bem o que quis dizer com esta série de cifras $[\ldots]$, esse ajuntamento pueril de palavras sem significado e de linhas sem sentido? (Kuntz, 1982, p. 19)

15. Que o Quadro provocou (e ainda provoca) controvérsias, não há dúvida. Mas num ponto, nos parece, salvo exceções, os economistas e os historiadores do pensamento econômico estão de acordo: se é complicado, se é difícil entender todas as facetas e todos os detalhes do Tableau Économique, suas linhas gerais, sua intenção genérica não é tão difícil de ser percebida e entendida. Trata-se, como já colocamos, de mostrar o circuito completo de um ciclo econômico equilibrado. Segundo os especialistas em Quesnay, a melhor explicação do Quadro está no texto “Análise da fórmula aritmética do Quadro Econômico” (1766). A partir desse, apontaremos aqui uma breve ideia de como Quesnay concebe esse circuito. Suponhamos, portanto, as três classes sociais. Trata-se, como nota Kuntz, de uma fórmula que descreve um esquema de reprodução simples, ou seja, sem acumulação. O estoque de capital já está constituído e apenas se repõe, ano após ano, enquanto a produção se repete (Kuntz, 1982, p. 54):

Suponhamos, portanto, um vasto reino, cujo território inteiramente cultivado, de acordo com os melhores métodos, proporcionasse, anualmente, uma reprodução no valor de cinco milhões, e onde o estado permanente 
desse valor fosse estabelecido com base nos preços constantes que têm curso entre as nações comerciais, enquanto se mantém, constantemente, uma livre concorrência de comércio, e uma inteira segurança da propriedade das riquezas de exploração da agricultura (Quesnay, 1978, p. 240).

16. Se colocarmos, agora, as três classes em jogo, suas riquezas e seu comércio, teremos o seguinte:

a) A classe faz adiantamentos anuais (i.e., despesas anuais que se fazem com o cultivo) de dois milhões. Os outros dois milhões são rendimentos. A classe dos proprietários tem dois milhões de rendimentos, dos quais um milhão são gastos em compras à classe produtiva, e o outro milhão em compras à classe estéril. A classe estéril tem adiantamento de um milhão, que são gastos na compra de matéria prima à classe produtiva;

b) Assim, a classe produtiva vende um milhão aos proprietários, e um milhão à classe estéril. $\mathrm{O}$ milhão que os proprietários despenderam com a classe estéril são empregados por esta classe na compra de produtos da classe produtiva. Então, o total das compras feitas pelos proprietários do rendimento e pela classe estéril soma três milhões;

c) Desses três milhões que a classe produtiva recebe, dois milhões ela deve aos proprietários, gasta um milhão com a classe estéril, e o circuito se fecha para recomeçar novamente.

17. Essa é, em linhas gerais, a maneira como funciona o quadro econômico de Quesnay. Trata-se, claramente, de um esquema de produção e circulação fechado, simples e repetitivo. É interessante notar que, no esquema de Quesnay, ele pensa o produto líquido, isto é, o excedente, ou o que Marx chama “a mais valia”. Mas, no Quadro, quando ele fornece uma representação social desse produto líquido, ele traz um detalhe particular: o fato de estar baseado no estudo das condições da reprodução, reprodução do capital social. Essa concepção da reprodução é inegavelmente dinâmica em Quesnay, Porque os 
adiantamentos são feitos no período que precedem repartição da colheita atual. Entretanto, essa dinâmica tem um caráter muito particular, porque ela funciona, por assim dizer, na base do princípio do eterno retorno do mesmo. Em suma, não há, em Quesnay, a ideia de acumulação do capital; isso porque a situação econômica que Quesnay visualiza se insere, ou melhor, insere os homens numa ordem natural, e a natureza nada mais é que o circuito fechado da semeadura à colheita. Nada está mais longe do pensamento de Quesnay que a ideia de progresso, tal qual, pelo menos, essa ideia é esboçada nos fins do século XVIII por Condorcet, no seu não menos famoso "Tableau", onde se delineia uma concepção da economia exatamente oposta à de Quesnay (Condorcet, 1971, p. 268-9).

18. A primeira versão do Tableau Économique apareceu em 1758; Quesnay fez publicar outras, sempre procurando melhorar e explicar com maior clareza isso que para ele era o máximo da clareza e que, no entanto, gerava tanta confusão. Em 1765 publica um texto capital, tanto para a compreensão de sua doutrina, como para os nossos propósitos. Trata-se do artigo "Direito Natural". Pode-se dizer que é a partir desse texto que a fisiocracia se constitui como uma escola, ou como um sistema global coerente. Este trabalho, entre outros aspectos importantes, tem dois principais: de um lado, ele representa um ajuste de contas de Quesnay com as diversas escolas do direito natural. A polêmica com Hobbes, p.ex., é muito clara. Mas há um outro aspecto do mesmo, e é esse que vai nos interessar, o qual revela, pela primeira vez, de modo claro, as concepções de Quesnay sobre os fundamentos e o funcionamento da sociedade. Esse texto tem uma articulação curiosa, na medida em que representa uma tentativa de síntese entre a concepção clássica do direito natural (cujas origens remontam ao livro V da Ética a Nicômaco, de Aristóteles) e as concepções recentes, sobretudo as de Locke - cuja influência sobre Quesnay é bastante considerável. Assim, p.ex., Quesnay define a justiça na 
linha direta do Direito Romano - mais especificamente inspirado em Cícero. Suas palavras:

Se me perguntarem o que é a justiça, eu responderei que é uma regra natural e soberana, reconhecida pelas luzes da razão que determina, evidentemente, o que pertence a nós mesmos ou a um outro (Quesnay, 1846, p. 42-3).

Se deixarmos de lado o caráter moderno da linguagem de Quesnay, não é difícil perceber que sua definição de justiça nada mais é que a velha fórmula do direito romano: Jus sum cuique tribuere. Na polêmica que estabelece com Hobbes, isso também fica claro. Essa pretensa ideia de que no estado de natureza os homens têm direito a tudo, i.e., que todos têm direito a tudo, é pura tagarelice, diz Quesnay. Num tal estado os homens estariam de tal maneira atrapalhados e preocupados em garantir sua própria subsistência, que não teriam tempo de ficar brigando continuamente com os outros. A luta pela subsistência pessoal torna inviável a luta com os outros homens e, nesse estado, a situação se resume naquilo que o homem pode conseguir pelo seu trabalho para a sua subsistência. Quesnay constrói uma imagem interessante para ilustrar sua ideia:

Pois seu direito a tudo é semelhante ao direito de cada andorinha a todos os mosquitos que esvoaçam no ar, mas que, na realidade, se limita àqueles que ela pode apanhar por seu trabalho, ou suas buscas determinadas pela necessidade (Ibid., p. 44).

19. E, dessa crítica de Hobbes - e aqui está outro traço marcadamente tradicionalista na concepção que Quesnay tem do direito natural - vai ficando claro que a hipótese de um estado de natureza, onde os homens vivem isolados, é mera quimera aos seus olhos. No capítulo IV do artigo sobre o direito natural Quesnay afirma que os homens podem ser considerados no estado de 
solidão, e no estado de multidão. Se considerarmos a primeira hipótese, os homens não têm nenhuma comunicação entre si, estão num total estado de independência. Mas, diz Quesnay, "este estado só pode subsistir o tempo de duração da vida de cada indivíduo" (Ibid., p. 49), o que significa a aniquilação da espécie. $\mathrm{Ou}$, então, se pode pensar que os homens viveriam, pelo menos cada um com uma mulher, o que exclui a primeira hipótese, pois essa associação com uma mulher e com filhos já cria uma ordem de dependência, de direitos e deveres, de segurança, de socorro recíproco, de justiça etc. (Ibid., p. 49) Ora, isso prova claramente a sociabilidade natural do ser humano, e o infundado da hipótese do estado de natureza. Esta é a proposição inicial do capítulo IV, que diz o seguinte:

A hipótese que supõe os homens isolados, e sem nenhuma comunicação uns com os outros, é absolutamente quimérica (Ibid., p. 49).

Le Trosne, um discípulo de Quesnay, desenvolve um argumento similar:

O homem isolado que, sem relação com seus semelhantes, vivesse da colheita, não estimaria suas produções além da utilidade pessoal; limitaria a extensão de seu cultivo aos seus consumos, e não trabalharia para criar um excedente que lhe seria inútil. Dessa maneira, o menor acidente físico poderia reduzi-lo a carecer do necessário, e não poder abarcar vários cultivos, e cumprir com todos os trabalhos prévios. Viveria em privação quase geral (Le Trosne, 1967, p. 223).

É necessário, portanto, a criação de excedentes; e isso só é possível quando há uma sociedade:

Com efeito, se os cultivadores trabalhassem somente para si mesmos, o valor seria indiferente: mas também limitariam seu trabalho à produção do mais necessário. Não haveria, em consequência, senão uma classe de 
homens ocupados na produção de sua subsistência, e cujas outras necessidades não seriam satisfeitas, senão de forma muito imperfeita. Por suposto, não haveria sociedade. [...] É, pois, o excedente, que provê os cultivos mais além dos gastos, que dá existência à sociedade [...] (Ibid., p. 237).

$\mathrm{E}$, como isso é possível? Le Trosne, ainda ele, responde com toda clareza:

Mas basta que duas famílias se estabeleçam uma perto da outra; forma-se entre elas uma associação natural de trabalhos e serviços, e o intercâmbio se apresenta para preencher todas as necessidades, estender as satisfações e fazer encontrar a cada uma, no seu excedente em seu gênero, os meios para adquirir no outro o que lhe falta (Ibid., p. 223).

20. Mas há também aspectos modernos na concepção que Quesnay elabora do direito natural. Dois, pelo menos, pode-se salientar. Em primeiro lugar, a própria definição de direito natural, que é dada por ele da seguinte maneira:

O Direito Natural do homem pode ser definido vagamente: o direito que o homem tem às coisas próprias ao seu gozo (ou à sua fruição) (Quesnay, 1846, p. 41).

Não nos iludamos com o termo vagamente, que aparece no texto. Será exatamente essa a definição de Quesnay do direito natural. A expressão é usada apenas para indicar que Quesnay vai examinar, ao longo do artigo, quais são as condições que tornam essa definição verdadeira. De qualquer maneira, uma coisa fica clara: Quesnay tem uma concepção utilitarista do direito natural: trata-se de fruir, de gozar de bens. Esse aspecto utilitarista do seu pensamento aparece claramente no artigo "Evidence", que escreveu para a Enciclopédia. E aqui aparece um outro aspecto moderno do seu pensamento: além disto implicar numa ética hedonista, delineia-se, no pensador, uma concepção de mundo onde a 
utilidade - individual e social - é a utilidade que nos é fornecida pelos bens econômicos. E a medida dessa utilidade é-nos dada pelo Quadro Econômico. Como consequência, tem-se o estabelecimento de uma hierarquia de fins, e a definição do homem pelo seu ter, pela sua posse.

21. Há, enfim, em Quesnay, uma concepção que produz uma visão global do homem e da sociedade, a partir do econômico. No final do artigo sobre o "Direito Natural", ele diz o seguinte:

O fundamento da sociedade é a subsistência dos homens e as riquezas necessárias à força que deve defendê-las: assim, não haveria senão a ignorância que pode, p.ex., favorecer a introdução de leis positivas contrárias à ordem da reprodução e da distribuição regular e anual das riquezas do território de um reino (Ibid., p. 367).

Esse é um traço marcadamente moderno do pensamento de Quesnay. Seus discípulos desenvolveram essa concepção até as últimas consequências, sobretudo Dupont de Nemours e Mercier de la Rivière. O raciocínio, em suas linhas gerais, é muito simples: os homens têm necessidades fundamentais, as quais eles precisam satisfazer. Para isso, eles precisam de meios para atingir esse fim - entre os quais se destacam o trabalho e o conjunto dos meios que lhes são necessários para isso (propriedade mobiliária e imobiliária). Estes, portanto, são direitos naturais dos homens e, portanto, a base e o liame de toda sociedade são a propriedade e a troca (Dupont de Nemours, 1846, p. 367-9). A sociedade nada mais é, portanto, que a expressão desse conjunto de exigências inelutáveis, o qual ela deve apenas consagrar:

Os homens, entretanto, não se reuniram por acaso em sociedades civis. Não foi sem razão que eles estenderam a cadeia natural dos deveres recíprocos, que se submeteram a uma autoridade soberana. Eles tinham um alvo, essencialmente marcado por sua natureza, para se conduzir assim. 
Ora, sua constituição física, aquela dos outros seres que os rodeiam, não permite que os meios para se chegar a esse alvo sejam arbitrários; porque não pode haver nada arbitrário nos atos físicos tendendo a um fim determinado. [...] Há, portanto, uma rota necessária para se aproximar o máximo possível do objeto da associação entre os homens, e da formação dos corpos políticos (Mercier de la Rivière, 1967, p. 189).

22. E, a partir desses princípios econômicos básicos, os fisiocratas desenvolvem uma concepção global do mecanismo e do funcionamento da sociedade que ultrapassa, em muito, o que hoje nós chamamos uma teoria econômica. No limite, tudo é deduzido a partir de certas premissas econômicas, mas as consequências ultrapassam muito o puro campo da economia. Mercier de la Rivière coloca o seguinte:

Propriedade, Segurança, Liberdade, eis aqui, então, a ordem social em sua totalidade; é dali, do direito de propriedade, mantido em toda sua extensão natural e primitiva, que vão derivar-se necessariamente todas as instituições que constituem a forma essencial da sociedade: podeis olhar esse direito de propriedade como uma árvore, da qual todas as instituições sociais são os ramos que dela crescem, que dela se nutrem e que morreriam quando dela se desprendessem (Ibid., p. 189).

23. Esses textos - e haveria tantos outros para citar - mostram claramente, parece-nos, que o movimento fisiocrata, além de ser uma teoria econômica, não se reduz a isso. Ele não se contenta em ser pura e simplesmente uma análise da produção, circulação e consumo dos bens econômicos. Não é só uma ciência das riquezas de uma nação, mas vai muito além disso, e acaba por englobar uma teoria jurídica, política e social, além da econômica. É exatamente essa restrição da disciplina que lamenta Dupont de Nemours, já velho, cansado, doente e exilado, numa longa carta que escreveu a J. B. Say: 
Você reduziu demasiadamente a carreira da economia política, ao tratá-la como a ciência das riquezas. Ela é a ciência do direito natural aplicado, como deve sê-lo, às sociedades civilizadas. E a ciência das constituições, que ensina e que ensinará, não só o que os governos não devem fazer por seu próprio interesse, pelo de suas nações, ou de suas riquezas, senão também o que não devem poder diante de Deus, sob pena de vencer o ódio e o desprezo dos homens, o destronamento durante sua vida, e o flagelo sangrento da história, depois de sua morte (Dupont de Nemours, 1967 , p. 136-7).

\section{E, um pouco mais à frente:}

Como você vê, meu querido Say, nossa ciência tem grande extensão, abraça um grande número de objetos. Por que restringi-la ao das riquezas? Saia de seu gabinete, passeie pelos campos; trata-se de todas as vontades do Criador em relação à nossa espécie. Seu talento é vasto; não se aprisione nas ideias e no idioma dos ingleses, povo sórdido que pensa que um homem não vale mais que pelo dinheiro que dispõe; que designa a coisa pública com as palavras "riqueza comum" (Common-Wealth), como se não existissem a moral, a justiça, o direito das gentes [...] (Ibid., p. 160-1).

24. Mas, num certo sentido, pode-se ir mais longe ainda e afirmar que Dupont de Nemours foi até discreto com relação à extensão ou ao domínio da teoria fisiocrática. Somos levados a pensar que ela constitui uma vasta e coerente teoria a respeito dos fundamentos últimos da sociedade e que ela contém explicitamente uma filosofia política, que é a que mantém todo esse edifício de pé, Aqui, como quase sempre, Quesnay limitou-se a dar as indicações gerais, e seus discípulos desenvolveram as ideias.

25. Todos os discípulos de Quesnay são unânimes em afirmar que a legislação positiva não cria coisa alguma; que ela se constitui apenas num conjunto de atos declaratórios: 
As ordenações dos soberanos, a que chamamos leis positivas, não devem ser nada mais que atos declaratórios (Ibid., p. 347).

E um pouco mais à frente:

Assim, o que chamamos poder legislativo, não pode ser o de criar, senão o de declarar as leis e de assegurar a sua observância.

Ainda, Mercier de la Rivière, fala o seguinte:

Sendo assim, a propriedade, para cada homem, necessariamente, a medida da liberdade de que deve gozar, é evidente que as leis positivas já estão todas feitas: que não podem ser mais que atos declarativos dos deveres e dos direitos naturais e recíprocos, os quais estão todos contidos na propriedade... (Mercier de la Rivière, 1967, p. 189).

Este texto de Rivière nos auxilia enormemente na compreensão da concepção da legislação positiva que têm os fisiocratas. Retomemos o fio do raciocínio a partir da noção de direito natural, tal qual é concebida por Quesnay.

26. Se o direito natural dos homens consiste nas coisas a que eles têm o direito de fruição ou gozo, e se isso engendra a necessidade do trabalho e da propriedade mobiliária e imobiliária, então essas exigências inalienáveis e suas consequências não só constituem os fundamentos da sociedade, como também constituem as leis fundamentais que devem regular toda a organização da sociedade. Assim, existe um conjunto de leis primitivas através do qual toda sociedade se organiza, e se organiza da melhor maneira possível. E como só há uma boa maneira de organizar a sociedade - que é o respeito a essas leis primitivas, então toda legislação positiva se resume - não em criar nada - mas apenas em respeitar e explicitar esse conjunto de leis primitivas. Enfim, a legislação 
positiva nada mais é que o ato de reconhecer e assumir - declarar, dizem os fisiocratas - a legislação que emana da natureza mesma. Lei positiva e lei natural são idênticas, ou devem ser idênticas; e, caso os legisladores constituam leis (no sentindo amplo do termo) que se desviem das leis emanadas pela natureza, eles só podem estar conduzindo a sociedade à sua própria dissolução.

27. Existem assim, para Quesnay e os fisiocratas, um conjunto de "leis constitutivas e fundamentais de todas as sociedades" (Dupont de Nemours, 1967, p. 337). Essas leis podem ser físicas ou morais, mas essa distinção não implica, para Quesnay e seus discípulos, nenhuma oposição do tipo matéria/espírito; pensamento/ extensão etc. No fundo, todas as leis são físicas. O moral não é senão um aspecto do físico.

Entre nós, para nós, tudo é físico, e o moral daí deriva (Ibid., p. 337$)^{4}$.

Mas nem é preciso levar em consideração esta nota, para se chegar a essa conclusão. Basta ler com atenção a definição de lei natural que Quesnay nos dá, no artigo sobre direito natural:

Para conhecer a ordem dos tempos e dos lugares, para regular a navegação e assegurar o comércio, foi necessário observar e calcular com precisão as leis do movimento dos corpos celestes. É necessário proceder da mesma maneira para conhecer a extensão do direito natural dos homens reunidos em sociedade, fixar-se nas leis naturais constitutivas do melhor governo possível [...]. Os homens reunidos em sociedade devem, portanto, estar sujeitos a leis naturais e a leis positivas. As leis naturais são físicas ou morais. Entende-se aqui por lei física o curso regulado de todo aconteci- 
mento físico da ordem natural, evidentemente o mais vantajoso para o gênero humano. Entende-se aqui por lei moral, a regra de toda ação humana da ordem moral, conforme a ordem física evidentemente a mais vantajosa para o gênero humano. Estas leis juntas formam o que chamamos de lei natural (Quesnay, 1967, p. 52-3).

Desnecessário dizer que, para Quesnay, "a legislação positiva consiste, portanto, na declaração das leis naturais” (Ibid., p. 53-4).

28. A insistência de Quesnay, mas, sobretudo, de seus discípulos, nesse fisicismo chega, às vezes, a ser maçante. Segundo Dupont de Nemours:

1) Ora, sua constituição física e aquela dos outros seres que o rodeiam não permitem que os meios para alcançar esse fim (a sociedade) sejam arbitrários Dupont de Nemours, 1967, p. 337);

2) [sobre Quesnay]: ele aplicou toda penetração de seu espírito à pesquisa das leis físicas relativas à sociedade (Ibid., p. 338);

3) Existe uma sociedade natural, anterior a toda convenção entre os homens, fundada sobre sua constituição sobre suas necessidades físicas [...] (Ibid., p. 341);

4) Nesse estado primitivo, os homens têm direitos e deveres recíprocos de uma justiça absoluta, porque eles são de uma necessidade física e, por consequência, absoluta para sua existência (Ibid., p. 342).

Em Mercier de La Rivière, a questão não se dá de outra maneira. Vejamos apenas, outra vez, alguns exemplos:

1) Para destacar, todo o possível, as duas regras fundamentais que acabo de estabelecer segundo a própria ordem física, remontemo-nos à origem da sociedade (Mercier de la Rivière, 1967, p. $178)$; 
2) A proporção à contribuição à renda pública esteve, pois, desde a origem das sociedades, sujeita, por uma necessidade física, a uma medida certa e constante (Ibid., p. 179);

3) É, pois, evidente que numa sociedade formada, a lei mais essencial, a lei fundamental concernente ao imposto, é que não haja nada arbitrário [...]. Esta regra é de uma necessidade física (Ibid., 1967, p. 189).

29. Assim, em oposição direta a boa parte de seus contemporâneos, já que a lei natural deve ser consagrada pela lei positiva, para Quesnay a sociedade é o lugar, por excelência, do exercício e da plenitude do direito natural. Para Quesnay, diz R. Kuntz, "a vida social tende a reforçar, ao invés de extinguir, o exercício do direito natural" (Kuntz, 1982, p. 104). Isso é dito claramente por Quesnay no fim do artigo sobre o direito natural:

É, portanto, evidente que o direito natural de cada homem se estenderia, razão em que nos preocupamos com a observação das melhores leis possíveis, que constituem a ordem a mais vantajosa aos homens reunidos em sociedade (Quesnay, 1967, p. 55).

30. Todo esse edifício pacientemente montado, extremamente bem elaborado e coerente - que faz com que a teoria econômica seja muito mais que uma teoria econômica, mas sim uma filosofia política baseada na ideia de que o econômico é a base da sociedade, afinal, Quesnay diz textualmente que "o fundamento da sociedade é a subsistência dos homens” (Ibid., p. 54) -, todo esse edifício está baseado numa noção-chave, que constitui o fecho, a clef-de-voûte do sistema, que é a noção de ordem, ou melhor, a noção de ordem natural. Talvez o texto mais conhecido da escola fisiocrática - com exceção do de Quesnay - seja um texto de Dupont de Vemours onde essa ideia, na verdade, é mais apresentada que explicada: 
Existe uma rota necessária para aproximar-se o máximo que é possível do objeto da associação entre os homens e da formação dos corpos políticos. Há, portanto, uma ordem natural, essencial e geral, que contém as leis constitutivas e fundamentais de todas as sociedades; uma ordem da qual as sociedades não podem se desviar sem serem menos sociedades, sem que o estado político tenha menos consistência, sem que seus membros se encontrem mais ou menos desunidos e numa situação violenta; uma ordem que não se pode abandonar inteiramente sem operar a dissolução da sociedade e, logo, a destruição absoluta da espécie humana (Dupont de Nemours, 1967 , p. 337-8).

\section{Vejamos um outro texto:}

Existe, portanto uma ordem natural e essencial à qual as convenções sociais estão sujeitas, e essa ordem é aquela que assegura aos homens reunidos em sociedade o gozo de todos os seus direitos, pela observância de seus deveres. A submissão exata e geral a essa ordem é a condição única para que cada um deva e possa esperar com certeza a participação a todas as vantagens que a sociedade pode oferecer (Ibid., p. 343).

31. O que esses dois textos podem nos ensinar se os relacionamentos com o que vimos até agora? As leis positivas são leis meramente declamatórias; sua função não é outra senão explicitar e colocar a claro esse conjunto de "leis primitivas e fundamentais de toda sociedade", que constituem as "leis naturais e essenciais da ordem social" (Ibid., p. 350). Nem sempre, na verdade, elas conseguem isso, nos avisa Quesnay, já que:

A multidão de leis contraditórias e absurdas estabelecidas sucessivamente nas nações prova, manifestamente, que as leis positivas estão sujeitas a se desviar das regras imutáveis da justiça [...] (Quesnay, 1967, p. 43).

Assim, abaixo ou sob o conjunto das leis positivas delineia-se, já se esboçando uma hierarquia, o conjunto das leis naturais 
(físicas e morais) que atuam de forma coercitiva sobre os sujeitos e as sociedades. Citemos mais um excerto de Dupout de Nemours:

A natureza nos rodeou de leis supremas e de um encadeamento físico e inviolável de causas e efeitos que não deixam à nossa inteligência e à nossa liberdade senão o cuidado de estudá-los e de a eles conformar nossa conduta para aproveitar as vantagens que ela nos ofereceu, e evitar os males que eles nos trariam inevitavelmente se nos recusamos, se negligenciamos em nos esclarecer sobre a ordem que eles constituem, e de nos submeter àquilo que nos é prescrito (Dupont de Nemours, 1967, p. 350).

É a esse conjunto de leis férreas que estamos submetidos, sob pena de, não as observando, no limite sermos levados à aniquilação que constitui o conjunto das leis naturais.

32. As leis naturais delineiam e delimitam o campo da ação dos homens, assim como a forma de constituição da sociedade. Se elas são férreas e inflexíveis, isso não significa dizer que elas são más. Ao contrário, é o respeito a elas que leva os homens e a sociedade ao maior grau de felicidade possível, i.e., segundo Quesnay, ao máximo de fruição, com um mínimo de despesa. Essa é a razão fundamental do porque o direito natural só se realizar plenamente desde que sejam obedecidas as leis naturais. Na verdade, o gozo dos direitos naturais, diz Quesnay, só podia ser muito limitado no estado de pura natureza, já que aqui não há nenhum concurso e nenhuma ajuda mútua, e onde os fortes podem usar injustamente da violência contra os fracos. Já quando os homens entram em sociedade, desde que eles respeitem as leis naturais e procurem vantagens recíprocas, eles sem dúvida aumentarão seu gozo e assegurarão a permanência deste (Quesnay, 1967, p. 45) .

33. Nemours nos diz claramente que o conjunto das leis naturais (físicas e morais) constitui a ordem natural que é responsável pela constituição das sociedades: "há uma ordem natural, 
essencial e geral, que contém as leis constitutivas e fundamentais de todas as sociedades". É essa noção de ordem o fecho teórico do sistema fisiocrático. Existe uma ordem natural constituída pelo conjunto das leis naturais que dão origem ao direito natural humano e à constituição da melhor sociedade possível; melhor sociedade possível, cuja dinâmica essencial e básica está descrita, ou melhor, visualizada no Tableau Économique. Toda sociedade que respeitar essa ordem levará os seus membros à maior fruição possível dos bens e, portanto, à maior felicidade possível. Ao contrário, a não observância dessa ordem leva à dissolução do liame social e, no limite, ao perecimento da espécie. "O bem físico e o mal físico, diz Quesnay, o bem moral e o mal moral têm, portanto, evidentemente, sua origem nas leis naturais" (Quesnay, 1967, p. 48$)$.

34. Mais ainda, essa ordem natural tem duas características fundamentais:

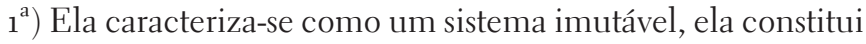
o "fundamento essencial e imutável do direito natural" (Ibid., p. 52) e todos os homens e as potências humanas devem a ela se submeter (Quesnay, 1967, p. 53). Mais ainda, elas foram instituídas por Deus e são as melhores que se pode conceber:

Essas leis soberanas, instituídas pelo ser supremo [...] são imutáveis e irrefragáveis e as melhores possíveis; por consequência, a base do governo, o mais perfeito, e a regra fundamental de todas as leis positivas, porque as leis positivas não são senão leis de manutenção relativas à ordem natural, evidentemente, a mais vantajosa ao gênero humano (Ibid., p. 53) .

Quesnay concebe que essas leis poderiam ser outras, mas argumenta que elas devem ser as melhores possíveis no vasto plano geral da criação: 
Outras leis teriam outras propriedades essenciais, verossimilmente menos conformes à perfeição, a qual o autor da natureza conseguiu na sua obra: aquelas instituídas são justas e perfeitas no plano geral, quando são conformes à ordem e aos fins a que Ele se propôs [...] (Ibid., p. 48) .

Por outro lado, argumenta Quesnay, se às vezes vemos desigualdades no plano do gozo do direito natural, devemos levar em conta que isso é o resultado das combinações das leis da natureza, e que os homens não podem penetrar nas intenções do ser supremo na construção do universo, e não podem se elevar à visão do destino das regras imutáveis que ele instituiu para a formação e a conservação de sua obra (Ibid., p. 46) .

$2^{\mathrm{a}}$ ) A segunda característica dessa noção de ordem natural é que ela se insere num conjunto maior, num vasto conjunto, nesse conjunto que é o universo totalmente regulado pela ordem, segundo os desígnios de Deus. O texto decisivo de Quesnay está numa nota inserida no capítulo $\mathrm{V}$, ainda no artigo sobre o direito natural. O texto não é muito claro, mas, na parte que nos interessa, ele não oferece problemas:

A ordem natural, a mais vantajosa aos homens, não é talvez a mais vantajosa aos outros animais; mas, no direito ilimitado, o homem tem aquele de fazer sua parte a melhor possível. Essa superioridade pertence à sua inteligência; ela é do direito natural porque o homem a tem do autor da natureza, que assim decidiu pelas leis que instituiu na ordem da formação do universo (Ibid., p. 53).

Assim, a ordem natural humana (que é uma ordem puramente física em dois sentidos: no sentido em que tudo é físico, e no sentido em que trata desde o início de relações do homem com a natureza, no sentido corrente) se insere numa vasta, numa 
enorme ordem que é a ordem cosmológica, ordem segundo a qual Deus construiu o universo. Eis um outro aspecto onde Quesnay é herdeiro do Direito Natural clássico.

35. Retomemos os pontos essenciais dessa noção de ordem, tal qual ela se explicita nos textos dos fisiocratas. Ela aparece, em primeiro lugar, como o conjunto das leis naturais que Deus instituiu na criação do universo. Essa ordem é imutável, inflexível, coercitiva e estabelece uma hierarquia que tem por finalidade a maior felicidade humana possível, i.e., a maior fruição dos bens que os homens podem obter através do exercício do trabalho. Assim, a ordem natural implica em ordem providencial.

36. A partir desse momento é praticamente impossível não relacionar o pensamento fisiocrata com a doutrina de Malebranche, que constitui, de ponta a ponta, uma filosofia onde a noção de ordem é central. Logo no início destes textos colocamos que vários autores já apontaram para essa relação. Um outro indício revelador da mesma é o fato de Mirabeau ter inserido todo o capítulo III, do "Tratado de Moral”, de Malebranche, que é dedicado ao "Amor da Ordem", na sua "Filosofia Rural" (Kuntz, 1982, p. 115), obra na qual Quesnay colaborou e escreveu todo o cap. VII. Mercier de la Rivière toma como epígrafe de sua obra sobre a ordem natural e essencial das sociedades um texto de Malebranche, do mesmo livro, que diz: “'A ordem é a lei inviolável, dos espíritos e nada é regulado se a isso não se conforma” (Malebranche, 1987, 115). Que há elementos malebranchistas no pensamento de Quesnay e dos fisiocratas, não há objeção. Com relação à Quesnay, a leitura do artigo "Evidência", e a do artigo sobre "direito natural", não deixam a menor dúvida. Resta saber qual a extensão dessa influência e se a concepção de ordem que se delineia nos fisiocratas é herdeira da mesma noção em Malebranche.

37. O pensamento de Malebranche é inteiramente dominado 
pela noção de Ordem, de uma ordem imutável e hierárquica de perfeições segundo a qual Deus organiza o cosmos e, sobretudo, o mundo dos valores. A ordem malebranchista aparece como um conjunto de perfeições que existem em si, válidas por elas mesmas, independentemente da vontade do sujeito (Gueroult, 1959, p. 33-4), e que são, ao contrário, obrigatórias para o sujeito.

De qualquer maneira, é bom assinalar que a noção de ordem em Malebranche envolve dois aspectos: ela deve ser considerada em relação ao conhecimento, e como lei para a vontade. As relações de perfeição que a constituem são, em primeiro lugar, especulativamente conhecidas no verbo como verdades, da mesma maneira que as relações de grandeza (as verdades especulativas, segundo Malebranche); e se tornam, por outro lado, normativas, na medida em que um juízo de amor se ajunta ao juízo de evidência, e impõe, invencivelmente, certa determinação ao movimento da vontade (Ibid., p. 36).

38. De qualquer forma, em Malebranche, a ordem é a hierarquia das perfeições em Deus; a justiça, o modo de agir e fazer segundo a ordem; a sabedoria, o conhecimento não só das verdades especulativas, mas das verdades da ordem. A sabedoria condiciona a justiça como ação, conforme a ordem. Pode-se dizer, em Malebranche, que Deus obedece à ordem, à justiça, ou que ele age conforme uma ou outra. Assim, já que Deus conhece todas as coisas que ele contém e, amando-as na proporção que são amáveis e estimáveis, ele ama imutavelmente essa ordem imutável, e ele é justo essencialmente e por si mesmo. Suas vontades são conformes à ordem. Esse é um ponto importante: Deus mesmo está submetido à ordem. Assim, a noção de desordem aparece como problemática em Malebranche porque, de um lado, não há como negá-la, e, de outro, pelas premissas da teoria, ela não tem lugar, de onde Malebranche conclui que, mesmo onde nós encontramos a desordem, ela deve ter sua explicação última na ordem, e ser explicada por ela. 
39. Os homens, por oposição, não são justos por eles mesmos, porque esta ordem imutável da justiça não se encontra neles, mas em Deus. Portanto, o grande problema da teoria malebranchista da ordem está no fato de que ela inclui essa ordem em Deus mesmo. E por causa disso, a essa ordem está submetida, de direito e de fato, a criação inteira. E, mais ainda, em virtude dessa premissa, a justiça e a ordem, independentemente de sua relação com a criação, aplicam-se então a Deus. E Malebranche define a ordem em Deus ${ }^{5}$ como consistindo nas "relações de perfeição que existem entre os atributos (perfeições absolutas) e entre as ideias que ele contém na sua substância (perfeições relativas)", o que implica em dizer que os atributos de Deus, considerados neles mesmos, têm valores diferentes: em si, a justiça vale mais que a onipotência etc. O que significa dizer que na filosofia de Malebranche a expressão "Deus agir como Deus", i.e., conforme a seus atributos, significa dizer que Deus não pode agir senão conforme a ordem de seus atributos. Eis o paradoxo da teoria malebranchista da ordem, quando ele a aloca em Deus: atributos absolutos na medida em que são absolutos não supõem, nem podem supor, nem hierarquia, nem diferença.

40. Na verdade, esse paradoxo é praticamente insolúvel na filosofia malebranchista e, se a teoria da ordem constitui uma noção-chave de seu sistema, ela envolve, por sua vez, um problema que parece sem solução. Para dizer, portanto, que os fisiocratas e, sobretudo, Quesnay são herdeiros da teoria malebranchista da ordem é preciso, pelo menos, tomar cuidado com essa afirmação, e procurar melhor entender o que isso pode significar.

41. É, na verdade, em Descartes que encontramos a teoria das 5 Em "Entretiens sur la Metaph...", VIII, parágrafo 13. 
verdades eternas, que influenciou Quesnay. Senão, vejamos. As duas noções de ordem, claramente delineadas. Uma delas submete a ordem inclusive a Deus. Caso de Malebranche e Leibniz. A ordem é superior à vontade de Deus, e a ela (a ordem) deve estar submetida. Deus também está submetido à ordem. Outra tese, compartilhada por Quesnay (conferir $\mathbb{3}$ 34), onde a ordem deve estar submetida à vontade de Deus. Essa tese é especificamente cartesiana.

42. É na famosa carta de 15 de abril de 1630 que irrompe, subitamente, essa tese. Basta ler o texto.

Que as verdades matemáticas, as quais você denomina de eternas, também foram estabelecidas por Deus, e dependem inteiramente, tanto quanto o resto das criaturas.

O excerto não pode ser mais claro: depende da vontade de Deus que $2+3$ sejam iguais a 5 . E, se Deus quisesse, outras relações se estabeleceriam, como, por ex., $2+3$ igual a 6 . E o texto tem uma continuação interessante:

É, com efeito, falar de Deus como Júpiter ou Saturno, e sujeitá-lo às stix e aos destinos, falar que essas verdades são independentes dele.

Quer dizer que os constata passivamente. Para falar mais claro, a concepção que tem da liberdade divina contraria uma concepção onde as verdades matemáticas fazem parte do entendimento divino, como se Deus as constatasse passivamente, malgrado ele mesmo. Enfim, Deus está sujeito a uma coisa, está, vamos dizer assim, submetido a ela, o que entra em contradição, segundo Descartes, com a liberdade divina.

43. Assim, "Deus estabeleceu as leis da natureza, assim como um rei estabelece leis em seu reino". Numa outra carta, de o6 
de maio de 1630, Deus as conhece como verdadeiras, porque ele quer que a sejam. Isso fica mais do que claro:

Sunt tantum vera aut possibles, qui Deus illas veras aut possibles cognoscit, nom autem contra veras a Deo cognosci quase independenter ab illo sunt vera.

\section{E adiciona:}

Se os homens entendessem bem o sentido das suas palavras, eles não poderiam jamais dizer, sem blasfêmia, que a verdade de algo precede o conhecimento que Deus tem, porque em Deus é uma só e mesma coisa o querer e o conhecer; de maneira que, disso mesmo que ele quer, ele conhece por aí essa coisa e, somente assim, tal coisa é verdadeira.

E, por fim, qual a necessidade de Deus ao criar essas verdades? Tudo isso está na liberdade de Deus, e nada o impediria, portanto, de fazer com que $2+3$ fossem iguais a 5 , como nada obsta que Ele criasse um mundo totalmente distinto deste que nós vemos, porque é uma mesma coisa: querer, entender e criar, sendo que uma não precede a outra, mesmo logicamente.

44. O mesmo vale para a moral:

A razão da bondade (das coisas) depende do que Deus quer fazer. E não há necessidade de questionar em qual gênero de causa essa bondade, nem todas as outras verdades, tanto matemáticas quanto metafísicas, depende de Deus (Respostas às sextas objeções, VII).

45. E não se pense que é só um arroubo de juventude. Nas cartas a Chanut $\left(1^{\circ}\right.$. de fevereiro de 1647), nos Entretiens avec Burman, bem como na carta a Arnauld (29 de julho de 1648), a mesmíssima posição é defendida. Por exemplo, na missiva a Arnauld: 
Para mim, me parece que não se deve dizer que alguma coisa é impossível para Deus, porque tudo o que é verdadeiro e bom, sendo na dependência de sua onipotência, eu não ouso mesmo dizer que Deus não pode fazer uma montanha sem vale, ou que $1+2$ não façam 3; mas digo somente que me é dado um espírito de tal natureza que eu não posso conceber uma montanha sem vale.

Enfim, Deus, na sua liberdade, é capaz de fazer o que um espírito finito não é capaz de conceber. Mas isso não significa dizer que, dada sua onipotência, isso não é realizável aos olhos de Deus. Então, veja-se bem, as verdades eternas exprimem as relações necessárias das coisas. Essas coisas dependem de Deus, tanto da sua existência, quanto da sua essência. E se há algumas coisas impossíveis, o é no terreno de outra ordem: por ex., Deus mentir.

46. Agora nós vislumbramos melhor o que há de diferente entre Malebranche e Descartes. Nas palavras de Gueroult, que resumem admiravelmente bem esse desacordo, a razão está em que, segundo Malebranche, Deus não pode nada criar que seja liberto das condições postas pela Ideia concebida como possível; para Descartes, ao contrário, Deus pode criar tudo, o possível e o impossível: "Eu tenho por assegurado e creio firmemente que Deus pode fazer uma infinidade de coisas, que nós não somos capazes de entender, nem de conceber" (Respostas às quartas-objeções, 7).

47. Uma vez sendo criado o mundo, as verdades lógicas e físicas são para sempre, senão fere-se o princípio da imutabilidade divina. Quer dizer, uma vez postos esses princípios, que Ele livremente escolheu, não há como mudar essas verdades, porque uma vontade que se corrige ela mesma, não é senão uma vontade inconstante e, por consequência, afetada de um defeito. De qualquer maneira, o conceito de possibilidade é equívoco: sendo um para Deus, outro para o gênero humano. O que é transparente 
para Deus - a união da alma e do corpo; a encarnação; a transubstanciação - é perfeitamente impenetrável para o gênero humano, mas, dada a onipotência de Deus, isso é perfeitamente realizável no plano divino.

48. Ora, a influência do pensamento de Santo Agostinho sobre Descartes é inegável, e ninguém contesta isso. Particularmente sua doutrina da ordem, da justiça parece inspirar-se diretamente em Santo Agostinho ${ }^{6}$, que, aliás, viu-se frente a um problema extremamente semelhante ao de Descartes. No "De Ordine", depois de haver afirmado que Deus governa tudo pela ordem: "não somente Deus conduz todas as coisas, mas sua ação, ela mesma, está submetida à ordem"7, e que essa ordem vem e permanece Nele $\mathrm{N}^{8}$, ele nota que todas as expressões dessa ordem (harmonia entre coisas opostas, justiça como repartição equitativa das recompensas e punições entre os bons e maus) supõem, necessariamente, algumas distinções. É isso que faz com que, logo depois, no De Natura Boni, a posição se inverta. Essas distinções são impossíveis, se tudo é bem: "ali onde tudo é bem, a ordem não existe, porque existe uma soberana igualdade, qual a ordem não é necessária"9. O problema é colocado com todas as letras por Santo Agostinho:

Com relação à questão: se Deus governa tudo com ordem, é em virtude dessa mesma ordem que ele se rege a si mesmo, ou essa ordem preside ao governo de todas as coisas, sem que Ele esteja compreendido ${ }^{10}$ ?

6 Grande parte dos medievalistas posteriores a Santo Agostinho interpretaram assim. Por ex., "Diz Santo Agostinho que não há coisas mais eternas do que o conceito de círculo, e que $2+3$ são 5 . Mas a verdade dessas coisas é uma verdade criada. Logo, a verdade criada é eterna" (São Tomás de Aquino, questão 16, artigo 7.1.).

7 "De Ordine", I, 10, parágrafo 29.

8 Id., ibid., cap. 7.

${ }_{9}$ Id., ibid., II, Cap. I, parágrafo 2.

10 Id., ibid. 
A outra questão também é abarcada claramente por Santo Agostinho: afinal, afirmar que Deus é o bem absoluto não significa dizer que Ele é estranho à ordem, e que essa ordem, regendo todo o existente, rege tanto o bem quanto o mal? Assim, quando falamos que a ordem rege tudo o que existe, não falamos somente no bem, o que permite, então, afirmar: "as coisas tomadas no seu conjunto são governadas por Deus, e o são pela ordem" ${ }^{11}$. Mas, no "De Ordine", Santo Agostinho acaba desembocando nos mesmos problemas que Malebranche, porque essa doutrina supõe que a ordem sempre existiu, solução maniqueísta que deve ser afastada.

49. Mas esse impasse deixa várias questões, tais como: em relação a que se determina a hierarquia de todos os bens? É uma sabedoria, uma justiça à qual se remete a vontade criadora ou o ato mesmo dessa vontade onipotente? A lei da justiça, que constitui a ordem em Deus, obriga a vontade divina exteriormente, ou é expressão da sua própria natureza? A vontade de Deus é distinta de sua razão, e governada por ela, ou razão e vontade estão unidas Nele de uma maneira que nos escapa?

50. Existe um outro conjunto de textos de Santo Agostinho que esboça uma solução mais coerente para esses problemas. Trata-se dos textos contra os Maniqueus. Neles Santo Agostinho distingue duas ordens: uma que reside em Deus e que caracteriza suas ações, e outra que reside nas coisas, e que constitui a adequação da coisa com o tipo ou a natureza que a constitui essencialmente. Em Deus, a ordem ou a justiça é concebida de uma maneira extremamente genérica: trata-se, não de uma lei regendo a hierarquia de seus atributos, determinando assim invencivelmente e a priori a vontade criadora a agir de tal ou tal maneira, para realizar tal ou tal fim. Trata-se, ao contrário, de 
uma vontade que, sendo onipotente, porque perfeita, está sempre apropriada aos fins que arbitrariamente se propõe. Nada, portanto, pode impedir Deus de criar aquilo que ele quer criar, já que é onipotente e, em virtude dessa onipotência, sua criação só pode ser perfeita. Ele cria perfeitamente aquilo que quer criar. Desse ponto de vista, não haverá jamais uma distância entre o criado e sua essência, já que a obra divina é sempre perfeita. E, o próprio fato de sua existência atesta sua bondade, já que o mal consiste no não ser. Assim, todo ser é, ipsofacto, bom. Isso é afirmado nos seis primeiros capítulos do "Da natureza do Bem", e, no limite, no cap. IV:

A natureza má é, pois, aquela que está corrompida, porque a que não está corrompida é boa. Mas, ainda assim, corrompida, é boa enquanto é natureza, e enquanto está corrompida é mán ${ }^{12}$.

51. Dessa maneira esboça-se em Santo Agostinho uma teoria da ordem que escapa tanto aos paradoxos da teoria malebranchista, quanto àqueles esboçados no "De Ordine". Agora se pensa a noção de ordem sob dois aspectos. Em primeiro lugar, a ordem em Deus que é a perfeita e necessária apropriação de sua ação ao seu fim: a ordem nas coisas como adequação das coisas criadas àquilo que Deus quis criar, o que implica, nessas coisas, uma lei orgânica ou harmônica condicionando e conservando a natureza perfeita do todo que a vontade divina decidiu colocar no plano da existência. As demais coisas, que são feitas do nada e que, certamente, são inferiores ao espírito racional, não podem ser nem felizes nem infelizes. Mas como são boas, enquanto a sua ordem e a sua beleza, Fonte do Sumo Bem, quer dizer, de Deus, receberam a bondade, por muito pequena e insignificante que esta seja, foram ordenadas de tal maneira que os mais débeis se subordinam 
aos mais fortes, os mais frágeis aos mais duráveis, os menos potentes aos mais poderosos, e assim também o terreno se harmoniza com o celestial, em subordinação do inferior ao superior e mais excelente $^{13}$. Essa lei é, ao mesmo tempo, uma lei de coordenação, de relações recíprocas, e uma lei de subordinação do inferior ao superior. Como diz admiravelmente Santo Agostinho no Contra Faustum:

Ele é o único que verdadeiramente pode ser dito como onipotente, porque existe verdadeiramente, e porque Dele só provem tudo isso que de qualquer modo existe, seja espiritual seja corporal, e porque Ele se serve de toda criação como Lhe apraz e a Ele apraz, segundo a justiça verdadeira e imutável, que ele mesmo é, tudo é mutável: e por ser Ele imutável, o muda em conformidade com o mérito da natureza ou das ações ${ }^{14}$.

52. Bem, daí a consequência que, em virtude da ordem, Deus ama o bem e detesta o mal' ${ }^{15}$, i.e., o não-ser que tenta limitar e corromper o ser que ele criou e se opõe à ordem divina, i.e., a perfeita adequação da coisa criada à sua forma. $\mathrm{O}$ que fica claro nesses textos de Santo Agostinho é que Deus executa sempre perfeitamente o que quer e, qual seja o mal que possa em aparência existir no mundo, esse mesmo mundo possui uma plena perfeição intrínseca constituída pela lei da harmonia ou justiça. A imperfeição só aparece nas partes; o conjunto é perfeito. E, a lei e a justiça emanam da onipotência divina, sendo a desordem apenas uma aparência. Uma consequência disto é que ordem e lei da natureza são idênticas (quer dizer, ordem e lei não são estritamente idênticas, porque a ordem ultrapassa a lei). Sendo assim, ordem e natureza são a mesma coisa, quer dizer, é absurdo pretender ir além para procurar em seus atos uma razão, um princípio, uma ordem que a ultrapassaria em seus domínios:

13 "Da natureza do bem", cap. 8, 829.

14 Contra Faustum, $26 \mathrm{~s}$.

15 "De Ordine", I, p. 7. 
Porque pesquisar as causas da vontade de Deus, quando essa vontade é a causa de tudo o que existe. Portanto, àquele que pergunta porque Deus fez o céu e a terra, a resposta é: porque quis ${ }^{16}$.

53. É exatamente por essa teoria, por mais que Malebranche se diga discípulo de Santo Agostinho, que ele se afasta deste, e de maneira bastante clara. Pelo menos em três pontos:

1) Enquanto que em Malebranche, já que a ordem submete inclusive Deus, existem leis da natureza distintas das leis da ordem, já que as primeiras são temporais e arbitrárias, enquanto as segundas são eternas e necessárias. Já em Santo Agostinho não existem leis arbitrárias da natureza, distintas da lei eterna da ordem. Em outros termos, ordem e lei da natureza são estritamente idênticas em Santo Agostinho. É impossível conceber leis da natureza que não tenham uma necessidade absoluta.

2) Ordem e natureza não são idênticas, mas, inclusive, em Malebranche, se opõem frequentemente. Para obedecer à ordem é preciso lutar contra a natureza, segundo Malebranche.

A perfeição ou a virtude não consiste, portanto, em seguir a ordem da natureza, mas em se submeter em todas as coisas à Ordem imutável e necessária, lei inviolável de todas as inteligências e de Deus mesmo.

Já em Santo Agostinho ordem e natureza não faz senão uma mesma coisa. É impossível pretender distinguir uma da outra e, muito mais, de opor uma a outra. As desordens que vemos na natureza não são senão aparências, porque a natureza, por definição, é ordem.

3) Por último, para Malebranche, somente a ordem é inviolável, não a lei natural. Já para Santo Agostinho, toda a natureza, 
assim como a ordem, é inviolável, e uma ação de Deus contrária à natureza é impossível.

54. Feito este percurso, podemos retomar a questão da qual partimos: qual a relação da noção de ordem de Malebranche nos fisiocratas? Existem elementos extrínsecos e intrínsecos que mostram claramente a presença da filosofia malebranchista no pensamento fisiocrático. Mas, sobretudo a semelhança das fórmulas com relação à noção de ordem (essa regra ou lei imutável governante dos seres do universo) faz com que o leitor seja levado a pensar que Quesnay e seus discípulos nada mais tenham feito que aplicar a um domínio particular essa fórmula malebranchista, e encará-la sobre um aspecto laico. Além disso, em ambos os sistemas de pensamento um mesmo problema, em gênero, se coloca: o da desordem, que se configura em múltiplos aspectos em Malebranche, desde a desordem puramente natural (os monstros, por ex.), até a desordem psico-intelectual (o erro, por ex.), mas que, neste, se resumem no problema do Mal e do pecado original. Já nos fisiocratas a desordem toma a forma do desvio: como as sociedades podem se desviar do reto caminho de sua felicidade e prosperidade. Para Malebranche o grande problema é porque Adão pecou. Para Quesnay: por que Colbert fez o que fez? Em ambos os sistemas, há respostas para essa questão.

55. Mas, pese esse conjunto de semelhanças, acreditamos haver mostrado que a noção de ordem natural que é utilizada pelos fisiocratas é herdeira mais direta da concepção agostiniana de ordem, do que da concepção malebranchista. Pelo menos em seus pontos essenciais:

1) Nós vimos que para os fisiocratas existe uma ordem universal, cosmológica instituída por Deus ${ }^{17}$; 
2) Que no interior dessa totalidade existe uma ordem natural composta do conjunto das leis naturais às quais os homens estão submetidos ${ }^{18}$;

3) Que essa ordem é instituída por Deus, mas ele mesmo não está submetido a ela ${ }^{19}$.

Neste ponto nos damos o direito de divergir do Prof. R. Kuntz, embora ele seja um especialista dos mais competentes no assunto. O Prof. Kuntz insinua que Quesnay parece hesitar neste ponto. Leiamos seu texto:

Bem definida quanto ao caráter transcendente e objetivo da ordem, a posição de Quesnay é menos nítida, no entanto, quanto à relação entre Deus e essa ordem. Ela aparece, frequentemente, como algo subordinado à vontade Divina, como "produto da vontade suprema do criador". No entanto, ele também apresenta as leis como as melhores possíveis - como se o autor, enfim, não pudesse, por sua natureza, haver criado outros princípios $^{20}$.

Temos a impressão que o texto de Quesnay não deixa margem a dúvidas:

Outras leis teriam outras propriedades, essências verossimilhantemente menos conformes à perfeição à qual o autor da natureza criou sua obra; aquelas que ele criou são justas e perfeitas, no plano geral, porque são conformes à ordem e aos fins que propôs, porque é ele mesmo o autor das leis e das regras e, por consequência, superior às leis e às regras ${ }^{21}$.

18 Nemours. "L’Origine et Progréss..." in Daire, p. 337.

19 "Direito Natural", p. 48 e 53.

20 Kuntz, R. Op. cit., p. 114-5. "E os homens, não podendo penetrar nos planos do ser supremo sobre a construção do Universo, não podem elevar-se até o destino das regras imutáveis que ele instituiu para a formação e a conservação de sua obra” (grifo nosso). Quesnay. "Droit Naturel" in Daire, op. cit., p. 46

21 Quesnay. "Direito Natural”, p. 48. 
Ora, nós acabamos de ver que em Santo Agostinho se delineia uma teoria da ordem onde Deus é superior à ordem das coisas criadas, e essa ordem é a melhor possível. A incompatibilidade ou problema só aparece quando nós queremos aproximar o esquema dos fisiocratas do esquema malebranchista, no sentido estrito. Ou, ainda, à concepção Leibniziana do universo, como faz L. Dumont no "Homo Aequalis"

4) Que essa ordem pode produzir efeitos colaterais indesejáveis, e pode ser objeto de desvios pela ação dos homens. Trata-se de dois casos diferentes.

No primeiro caso, o próprio curso da ordem pode provocar efeitos colaterais maléficos e indesejáveis. O exemplo clássico está em Quesnay, ainda no artigo "Direito Natural":

Entretanto, se examinarmos essas regras com atenção, perceberemos, ao menos, que as causas físicas do mal físico são as mesmas causas dos bens físicos, assim como a chuva que incomoda o viajante, fertiliza as terras. Se calcularmos sem prevenção, veremos que estas causas produzem infinitamente mais bem do que mal e que só são instituídas para o bem; que o mal que elas causam por acidente resulta, necessariamente, da própria essência das propriedades pelas quais elas operam o bem²3.

Esse exemplo faz com que nos lembremos quase que involuntariamente do mesmo, ou quase o mesmo exemplo, que é dado frequentemente por Malebranche ${ }^{24}$. Certo, a semelhança dos exemplos e da intenção que está contida neles é a mesma.

22 Dumont. Op. cit., p. 53.

23 In Daire, Op. cit., p. 46.

24 Nas "Méditations Chrétiennes et Métaphysiques" (Oeuvres Completes, T. X. Paris: Vrin, 1967, p. 121) lemos, com efeito, o seguinte exemplo: "Dieu fait pleuvoir dans le deffein de rendre les terres fécondes, et cependant il pleut fur les fablons et dans la mer; il pleut dans les grands chemins: il pleut également dans les terres inégalement cultivées. N'estil pás évident par tout ceci que Dieu n'agit point par des volontez particuliéres?" 
Mas, não nos esqueçamos, é uma explicação agostiniana, conforme nós vimos.

No segundo caso, o dos desvios, o que está em questão é a liberdade humana, liberdade esta que não consiste numa intervenção ativa, mas, quase sempre, numa não observância das leis. Em todo caso, não se trata de uma violação da lei, mas de um mau uso dela. O Prof. Kuntz cita um caso elucidativo: posso, se quiser, me jogar num abismo, mas, há um alto preço a pagar por isso. No caso específico dos fisiocratas, estes desvios se constituem num desrespeito constante e contínuo à lei natural fundamental de que a terra é a fonte de toda riqueza, i.e., num desprezo à agricultura que leva as sociedades à decadência e, no limite, ao colapso:

As transgressões das leis naturais são as causas mais extensas e mais comuns dos males físicos que afligem os homens; mesmo os ricos, que têm mais meios de evitá-los, atraem para si, por sua ambição, por suas paixões, e mesmo por seus prazeres muitos males pelos quais somente seu desregramento pode ser culpado. Isso nos leva insensivelmente a uma outra causa do mal físico e do mal moral, que não é do mesmo gênero que as leis físicas: é o mau uso da liberdade dos homens. A liberdade, esse atributo constitutivo do homem, que o homem gostaria de estender para além de seus limites, a este parece nunca estar errada; se ele faz mal a si mesmo, se destrói a sua saúde, se acaba com seus bens e arruína sua família pelo mau uso da liberdade, queixa-se do Autor de sua liberdade, quando gostaria de ser ainda mais livre, não percebendo estar em contradição consigo mesmo 25 .

56. Com isso tudo, não se está querendo dizer que em Santo Agostinho os fisiocratas encontraram seu modelo de ordem natu-

25 Quesnay. "Droit Naturel" in Daire, op. cit., p. 46-7. No "Diálogo sobre o comércio" este afirma o seguinte: "Quando essa multitude de causas pelo esquecimento da ordem natural acarretou a destruição dos costumes, o Estado debilitado por todas as partes, não esperou, nem pode, nem deveria esperar senão a devastação e a escravidão" (In Los Fisiócratas, op. cit., p. 66). 
ral. Nem nos interessa saber se Quesnay e seus discípulos leram e meditaram Santo Agostinho. Isso é um problema secundário, do nosso ponto de vista. O importante é perceber que se trata do mesmo modelo teórico, aplicado num universo conceitual completamente diferente - já que nem a visão de mundo (influenciada pelo mecanicismo), nem a concepção de lei (uma concepção moderna, ausente em Santo Agostinho) - a produzir uma síntese original, original a tal ponto que delimitou um novo campo teórico: o da economia. Na verdade, o mais provável que tenha acontecido é Quesnay ter partido de Malebranche - e esboçado uma concepção de ordem natural a partir de sua leitura, concepção que, superficialmente, é a que se tem da noção de ordem em Malebranche - e aplicado esse esquema, sem saber que estava, na verdade, aplicando outro. Mas, aqui, entramos no terreno movediço da pura hipótese e, portanto, é hora de parar.

\section{Bibliografia}

BOISGUILBERT, P. "Detail sur le France". In Pierre de Boisguilbert ou la naissance de l'économie politique, 2 vols. Paris, Institut National d'Etudes Démographiques, 1966.

CANTILLON, R. Essai sur la nature du Commerce en general. Edited with an English translation and other material by Henry Higgs, C.B. Reissued for The Royal Economic Society by Frank Cass and Co., LTD., London. 1959.

CONDORCET. Esquisse d'un Tableau des Progrès de l'Esprít Humain. Paris: Ed. Sociales, 1971.

DEYON, P. O Mercantilismo. Lisboa, Gradiva, 1983.

DUMONT, L. Homo Aequalis. Paris, Gallimard, 1991.

FACARELLO, G. "Quelques réflexions sur l'equilibre économique chez P. Boisguilbert”. In Économies et Societés, T. XVIII, no. 3, março de 1984, série PE, no. 1. 
KUBOTA, A. “Quesnay disciple de Malebranche”. In Quesnay et la Physiocratie. Paris, Ined, $195^{8}$.

KUNTZ, R. Capitalismo e Natureza. São Paulo: Brasiliense, 1982.

LE TROSNE,G.-F. “Do interesse social com relação ao valor [...]”. In: Los Fisiócratas. Maxima III. Buenos Aires, LetraFirme, 1967.

DESCARTES, R. Obras escolhidas. Introdução de Gilles-Gaston Granger; prefácio e notas de Gérard Lebrun; tradução de Jacob Guinsburg e Bento Prado Jr. São Paulo, Difel - Difusão Europeia do Livro, 1962.

DUPONT DE NEMOURS. “Abragé des principles de l'economie politique”. In Les Physiocrates. Paris, Guillaumin, 1846.

. "Origine e prógres d'une Science nouvelle". In: Les Physiocrates. Paris, Guillaumin, 1846.

GUEROULT, M. Malebranche II. Les cinq abimes de la providence. I. L'ordre et l'occasionalisme. Paris, Aubier-Montaigne, 1959.

MALEBRANCHE, N. Traité de Morale. Paris, Vrin, 1987.

MARX, K. "História crítica da teoria da mais-valia”. In: 18 de Brumário. Buenos Aires, Clacso Libros, 1974 (Tomo 1).

MERCIER DE LA RIVIERE. "El orden natural e essencial de las sociedades politicas". In Los Fisiócratas. Maxima III. Buenos Aires: LetraFirme, 1967.

MONTCHRÉTIEN, A. de. Traité de economie politique (1615).

QUESNAY, F. "Máximas gerais de um reino agrícola” (1767). In Los Fisiócratas. Maxima III. Buenos Aires, LetraFirme, 1967.

"Segundo diálogo sobre os trabalhos dos artesãos". In Los Fisiócratas. Maxima III. Buenos Aires, LetraFirme, 1967.

QUESNAY. Les Physiocrates. Paris, Guillaumin, 1846.

Quadro Econômico. Lisboa, Fundação Calouste Gulbenkian, 1978.

RODIS-LEWIS, G. Malebranche. Paris, PUF, 1963.

SCHULL, P.M. "Malebranche et Quesnay". In Revue Philosophique de la France et de l'Etranger, 03/04/1938, nos. 3 e 4. Paris, Alcan, $193^{8}$.

SCHUMPETER, J. History of Economic Analysis. Oxford, Oxford University Press, 1967. 